\title{
BODY FLUID AND ELECTROLYTE COMPOSITION IN ARTERIAL HYPERTENSION. I. STUDIES IN ESSENTIAL, RENAL , AND MALIGNANT HYPERTENSION *
}

\author{
By W. HOLLANDER, $\dagger$ A. V. CHOBANIAN and B. A. BURROWS with the technical \\ ASSISTANCE OF VALENTINE BIKERMAN \\ (From the Robert Dawson Evans Memorial, Massachusetts Memorial Hospitals, the Radio- \\ isotope and Medical Services, Boston Veterans Administration Hospital, and the \\ Department of Medicine, Boston University School of Medicine, \\ Boston, Mass.)
}

(Submitted for publication August 29, 1960; accepted October 20, 1960)

In previous studies in this laboratory it was found that the capacity to excrete sodium as indicated by the rate of excretion of an intravenously administered sodium load was significantly increased in essential and renal hypertension (1, 2 ). Sodium excretory capacity was reduced by antihypertensive therapy and was correlated significantly with the level of arterial pressure. However, the absence of a high degree of correlation, together with the ability of dietary sodium intake to influence the renal capacity to excrete sodium, suggested that in addition to an elevated blood pressure other factors such as an increase in body sodium and fluid volume might enhance sodium excretion in hypertensive individuals.

Studies in Cushing's syndrome and Addison's disease by other workers suggest that the level of adrenal cortical activity may influence not only the renal capacity to excrete sodium but also the arterial pressure as well as the body's content of fluids and electrolytes $(3,4)$. In line with these observations are recent reports indicating that an increase in aldosterone activity occurs in certain groups of hypertensive subjects (5-7).

To clarify the relationship of arterial hypertension to alterations in adrenal cortical function and in electrolyte and water metabolism, it was decided to study body fluid and electrolyte composition in various forms of hypertension, including that associated with primary aldosteronism (8). The present report describes the findings in essential, renal and malignant hypertension. The observa-

\footnotetext{
* Supported by Contract AT(30-1)919 between the Atomic Energy Commission and the Massachusetts Memorial Hospitals.

$\dagger$ Special Research Fellow, National Institutes of Health.
}

tions in primary aldosteronism are presented in a separate report (9).

\section{CLINICAL MATERIAL AND METHODS}

Radioisotope dilution studies were performed in untreated ambulatory hypertensive patients and normal subjects who were paired as to age, sex, height, weight and body build. The dietary intake of salt as indicated by history and urinary sodium excretion over a 24 hour period was "unrestricted" and comparable in the hypertensive and the control subjects.

The 20 subjects with essential hypertension had sustained elevations of blood pressure with grade I to III retinopathy (Keith-Wagener) but without complicating nitrogen retention or congestive heart failure. However, 8 of these subjects were found to have enlarged left ventricles on roentgenographic examination.

The 10 subjects designated as having "renal hypertension" had a history of kidney disease which antedated the onset of the hypertension. Included in the group were 5 subjects with bilateral chronic pyelonephritis, 2 with polycystic kidney disease and 3 with glomerulonephritis. Their fundi showed grade I to III retinopathy whereas their blood urea nitrogen levels were normal except in 2 subjects. The left ventricle was enlarged in 5 subjects but no patient had complicating congestive heart failure.

The 7 hypertensive subjects with complicating heart failure had enlargement of the left ventricle with symptoms and signs of pulmonary congestion but without clinically detectable peripheral edema. The decholin circulation time was prolonged in all subjects but only 1 had a definite elevation of venous pressure. Two of the subjects had nitrogen retention and all showed grade II to III hypertensive retinopathy.

All 10 subjects who had malignant hypertension had grade IV retinopathy (papilledema) as well as marked elevation of blood pressure. In the group there were 4 subjects with chronic bilateral pyelonephritis, 3 with essential hypertension, 2 with glomerulonephritis, and 1 with renal arterial occlusion. Most of the subjects complained of fatigability and exertional dyspnea. They also had nitrogen retention as well as an enlarged left ven- 
TABLE I

Essential hypertension*

\begin{tabular}{|c|c|c|c|c|c|c|c|c|c|c|c|c|c|}
\hline Subject & Sex & Age & Body wt & BSA & BP & Fundi & BUN & $\begin{array}{c}\text { Serum } \\
\text { osm. }\end{array}$ & $\begin{array}{l}\mathrm{ECF} \\
\left(\mathrm{S}^{35} \mathrm{O}_{4}\right. \\
\text { space) }\end{array}$ & $\mathrm{Na}_{s}$ & $\mathrm{~K}_{\text {s }}$ & $\underset{\text { body wt }}{\mathrm{Nac} /}$ & $\begin{array}{c}\mathrm{K}_{\mathrm{e}} ! \\
\text { body wt }\end{array}$ \\
\hline & & $y r s$ & $\mathrm{~kg}$ & $m^{2}$ & $m m \mathrm{Hg}$ & grade & $m g \%$ & $m O s m / L$ & $\stackrel{c}{\text { body } w t}$ & $m E q / L$ & $m E q / L$ & $m E q / k g$ & $m E q / k g$ \\
\hline W.M. & M & 49 & 76.3 & 1.92 & $205 / 135$ & III & 14 & 296 & 15.3 & 137 & 3.5 & 33.5 & 45.6 \\
\hline M.S. & M & 49 & 71.8 & 1.83 & $225 / 125$ & II & 22 & 281 & 13.8 & 141 & 3.6 & 41.3 & 49.0 \\
\hline V.W. & $\mathrm{F}$ & 32 & 65.0 & 1.72 & $255 / 150$ & II & 13 & 288 & 13.1 & 144 & 4.1 & 37.1 & 30.9 \\
\hline M.D. & $\mathrm{F}$ & 36 & 70.5 & 1.72 & $195 / 125$ & II & 13 & 288 & 13.8 & 142 & 4.3 & 33.1 & 29.9 \\
\hline R.D. & $\mathrm{F}$ & 48 & 50.8 & 1.58 & $195 / 110$ & II & 17 & 286 & 14.7 & 147 & 3.7 & 38.0 & 32.6 \\
\hline H.L. & $\mathrm{F}$ & 44 & 65.4 & 1.61 & $220 / 115$ & II & 9 & 288 & 14.0 & 144 & 4.2 & 33.8 & 28.0 \\
\hline M.S. & $\mathrm{F}$ & 55 & 67.7 & 1.65 & $245 / 130$ & II & 13 & 290 & 14.7 & 138 & 3.8 & 29.5 & 27.7 \\
\hline J.W. & M & 46 & 83.2 & 2.00 & $205 / 110$ & II & 14 & 291 & 14.6 & 141 & 3.6 & 45.1 & 44.1 \\
\hline M.H. & $\mathrm{F}$ & 36 & 85.9 & 2.04 & $180 / 110$ & I & 15 & 286 & 12.4 & 142 & 4.1 & 39.3 & 35.7 \\
\hline A.L. & M & 50 & 67.8 & 1.77 & $235 / 145$ & II I & 17 & 283 & 16.2 & 141 & 3.9 & 41.5 & 42.1 \\
\hline D.C. & M & 58 & 86.3 & 1.95 & $195 / 125$ & III & 19 & 288 & 14.0 & 144 & 4.7 & 38.1 & 38.2 \\
\hline M.M. & $\mathrm{F}$. & 60 & 99.5 & 1.98 & $230 / 130$ & III & 20 & 297 & 15.1 & 141 & 4.2 & 33.9 & 26.1 \\
\hline C.A. & $\mathrm{F}$ & 34 & 104.5 & 2.10 & $180 / 125$ & I & 10 & 288 & 11.3 & 146 & 3.9 & 26.5 & 25.4 \\
\hline M.D. & $\mathrm{F}$ & 46 & 76.8 & 1.83 & $215 / 125$ & II & 13 & 281 & 14.7 & 145 & 4.5 & 35.1 & 30.3 \\
\hline H.B. & $\mathrm{F}$ & 47 & 55.3 & 1.55 & $185 / 110$ & II & 18 & 283 & 14.7 & 142 & 4.4 & 39.9 & 36.9 \\
\hline B.C. & M & 36 & 85.9 & 2.04 & $175 / 115$ & II & 14 & 290 & 12.7 & 144 & 4.2 & 32.3 & 35.1 \\
\hline H.B. & M & 35 & 74.1 & 1.95 & $180 / 125$ & II & 19 & 287 & 14.3 & 140 & 4.5 & 36.0 & 43.2 \\
\hline R.M. & $\mathrm{F}$ & 53 & 63.3 & 1.59 & $180 / 120$ & II & 16 & 302 & 13.9 & 140 & 4.2 & 42.1 & 30.4 \\
\hline G.H. & M & 54 & 79.3 & 1.94 & $175 / 110$ & I & 16 & 296 & 14.7 & 141 & 3.8 & 45.7 & 33.7 \\
\hline M.M. & $\mathrm{F}$ & 49 & 69.1 & 1.71 & $175 / 100$ & II & 12 & 286 & 14.2 & 142 & 4.2 & 39.3 & 36.5 \\
\hline \multicolumn{14}{|c|}{ Control } \\
\hline J.I. & $\mathbf{M}$ & 52 & 74.5 & 1.89 & $120 / 80$ & 0 & 18 & 286 & 15.8 & 139 & 4.0 & 41.2 & 39.9 \\
\hline J.L. & M & 48 & 70.4 & 1.88 & $105 / 70$ & 0 & 8 & 285 & 14.3 & 137 & 4.5 & 41.8 & 52.9 \\
\hline M.D. & $\mathrm{F}$ & 33 & 66.4 & 1.76 & $105 / 65$ & 0 & 12 & 279 & 15.9 & 138 & 4.3 & 38.0 & 35.0 \\
\hline J.M. & $\mathrm{F}$ & 34 & 70.9 & 1.76 & $120 / 80$ & 0 & 10 & 280 & 13.8 & 140 & 3.9 & 36.3 & 38.2 \\
\hline S.R. & $\mathrm{F}$ & 45 & 49.5 & 1.50 & $125 / 75$ & 0 & 17 & 289 & 17.0 & 140 & 4.2 & 36.7 & 43.2 \\
\hline A.J. & $\mathrm{F}$ & 43 & 66.3 & 1.65 & $100 / 65$ & 0 & 8 & 288 & 16.1 & 143 & 3.8 & 37.8 & 34.7 \\
\hline G.H. & $\mathrm{F}$ & 56 & 66.1 & 1.69 & $125 / 80$ & 0 & 15 & 284 & 14.8 & 143 & 4.1 & 34.5 & 32.4 \\
\hline A.F. & M & 49 & 81.8 & 1.91 & $125 / 75$ & 0 & 13 & 297 & 16.5 & 146 & 4.8 & 37.7 & 38.3 \\
\hline M. & $\mathrm{F}$ & 37 & 86.8 & 2.00 & 130,75 & 0 & 8 & 283 & 15.3 & 139 & 4.2 & 29.5 & 28.8 \\
\hline E.H. & $\mathrm{M}$ & 48 & 66.6 & 1.75 & $125 / 80$ & 0 & 19 & 289 & 14.0 & 140 & 4.3 & 42.0 & 40.5 \\
\hline S.P. & $\mathbf{M}$ & 62 & 85.0 & 1.95 & $125 / 80$ & 0 & 14 & 288 & 16.5 & 140 & 4.4 & 35.6 & 32.8 \\
\hline M.i. & $\mathrm{F}$ & 62 & 95.5 & 2.03 & $130 / 80$ & 0 & 18 & 292 & 13.5 & 140 & 4.5 & 32.6 & 26.7 \\
\hline E.V. & $\mathrm{F}$ & 39 & 108.9 & 2.13 & $135 / 85$ & 0 & 12 & 288 & 10.1 & $\begin{array}{l}140 \\
139\end{array}$ & 4.1 & 29.6 & 27.1 \\
\hline N.R. & $\mathrm{F}$ & 43 & 73.6 & 1.83 & $135 / 85$ & 0 & 7 & 283 & 14.6 & $\begin{array}{l}139 \\
140\end{array}$ & $\begin{array}{l}4.1 \\
3.9\end{array}$ & 30.7 & 32.6 \\
\hline M.M. & $\mathrm{F}$ & 41 & 52.0 & 1.51 & $115 / 75$ & 0 & 10 & 277 & 14.3 & 137 & 3.6 & 34.8 & 33.4 \\
\hline T.M. & M & 33 & 88.2 & 2.06 & $120 / 75$ & 0 & 17 & 287 & 13.5 & 145 & 4.5 & 35.2 & 42.9 \\
\hline H.T. & $\mathbf{M}$ & 36 & 74.5 & 1.97 & $120 / 75$ & 0 & 13 & 290 & 14.8 & 144 & 4.5 & 42.8 & 40.0 \\
\hline $\mathrm{E} . \mathrm{K}$. & $\mathrm{F}$ & 49 & 66.8 & 1.61 & $100 / 60$ & 0 & 12 & 287 & 14.2 & $\begin{array}{l}144 \\
140\end{array}$ & 4.5 & 33.9 & 30.4 \\
\hline H.D. & M & 52 & 80.3 & 1.95 & $115 / 80$ & 0 & 11 & 287 & 15.0 & 141 & 4.4 & 39.8 & 39.1 \\
\hline T.M. & $\mathrm{F}$ & 49 & 70.5 & 1.70 & $130 / 70$ & 0 & 14 & 286 & 14.1 & 138 & 3.5 & 32.6 & 32.3 \\
\hline
\end{tabular}

* $\mathrm{BSA}=$ body surface area. $\mathrm{BP}=$ blood pressure. $\mathrm{BLN}=$ blood urea nitrogen. Osm. =osmolality. ECF =extracellular fluid volume. $\mathrm{Na}_{\mathrm{s}}=$ serum sodium. $\mathrm{K}_{\mathrm{s}}=$ serum potassium. Na $=$ exchangeable sodium. $\mathrm{K}_{\mathrm{e}}=$ exchangeable potassium.

TABLE II

"Renal" hypertension

\begin{tabular}{|c|c|c|c|c|c|c|c|c|c|c|c|c|c|c|}
\hline Subject & Diagnosis* & Sex & Age & Body wt & BSA & $\mathrm{BP}$ & Fundi & $B L N$ & $\begin{array}{l}\text { Serum } \\
\text { osm. }\end{array}$ & $\begin{array}{l}\mathrm{ECF} \\
\left(\mathrm{S}^{35} \mathrm{O}_{4}\right. \\
\text { space })\end{array}$ & $\mathrm{Na}$ & $\mathrm{K}_{\text {s }}$ & $\underset{\text { body wt }}{\mathrm{Nae/}}$ & $\begin{array}{c}\mathrm{K}_{\mathrm{e}} / \\
\text { body-wt }\end{array}$ \\
\hline & & & $y r s$ & $\mathrm{~kg}$ & $m^{2}$ & $m m H g$ & grade & $m g \%$ & $m O s m / L$ & $\begin{array}{c}\% \\
\text { body wt }\end{array}$ & $m E q / L$ & $m E q / L$ & $m E q / k g$ & $m E q / k g$ \\
\hline J.W. & Pyelo. & M & 50 & 78.9 & 1.95 & $205 / 125$ & III & 33 & 296 & 16.0 & 140 & 5.0 & 39.6 & 34.7 \\
\hline V.C. & Pyelo. & $\mathrm{F}$ & 43 & 53.6 & 1.51 & $185 / 125$ & II & 13 & 287 & 13.0 & 139 & 3.9 & 32.4 & 40.8 \\
\hline A.G. & Pyelo. & $\mathrm{F}$ & 32 & 68.6 & 1.73 & $170 / 110$ & II & 16 & 283 & 13.8 & 141 & 4.4 & 39.4 & 32.4 \\
\hline G.A. & Pyelo. & $\mathrm{F}$ & 46 & 70.0 & 1.81 & $180 / 115$ & 1 & 21 & 287 & 12.5 & 143 & 3.9 & 37.5 & 32.7 \\
\hline B.R. & Pyelo. & $\mathrm{F}$ & 38 & 63.6 & 1.72 & $255 / 180$ & II & 17 & 292 & 12.2 & 134 & 3.6 & 30.6 & 34.6 \\
\hline G.R. & Polycyst. & M & 24 & 87.6 & 2.10 & $150 / 110$ & II & 14 & 287 & 13.0 & 139 & 3.9 & 32.4 & 40.8 \\
\hline M.C. & Polycyst. & $\mathrm{F}$ & 45 & 65.8 & 1.61 & $195 / 135$ & II & 23 & 283 & 16.2 & 141 & 4.3 & 42.9 & 32.8 \\
\hline M.M. & Neph. & $\mathrm{F}$ & 28 & 60.1 & 1.71 & $200 / 125$ & II & 13 & 288 & 15.6 & 144 & 4.0 & 33.1 & 31.0 \\
\hline G.T. & Neph. & M & 46 & 82.0 & 1.95 & $175 / 115$ & III & 20 & 288 & 15.4 & 140 & 4.8 & 35.9 & 49.1 \\
\hline A.G. & Neph. & $\mathrm{F}$ & 55 & 73.1 & 1.73 & $195 / 125$ & II & 20 & 289 & 14.1 & 143 & 4.0 & 31.0 & 30.9 \\
\hline \multicolumn{15}{|c|}{ Control } \\
\hline H.B. & Normal & $\mathbf{M}$ & 52 & 80.3 & 1.95 & $115 / 80$ & 0 & & & & & 4.4 & & 39.1 \\
\hline M.M. & Normal & $\mathrm{F}$ & 41 & 52.0 & 1.51 & $115 / 75$ & 0 & 10 & 277 & 14.3 & 137 & 3.6 & 34.8 & 33.4 \\
\hline J.M. & Normal & $\mathrm{F}$ & 34 & 70.9 & 1.76 & $120 / 80$ & 0 & 10 & 280 & 13.8 & 140 & 3.9 & 36.3 & 38.2 \\
\hline N.R. & Normal & $\mathrm{F}$ & 43 & 73.6 & 1.83 & $135 / 85$ & 0 & 7 & 283 & 14.6 & 140 & 3.9 & 30.7 & 32.6 \\
\hline M.D. & Normal & $\mathrm{F}$ & 33 & 66.4 & 1.76 & $105 / 65$ & 0 & 12 & 279 & 15.9 & 138 & 5.3 & 38.0 & 35.0 \\
\hline H.G. & Normal & $\mathbf{M}$ & 26 & 85.0 & 2.03 & 12585 & 0 & 17 & 297 & 14.7 & 145 & 4.2 & 38.7 & 36.4 \\
\hline A.J. & Normal & $F$ & 43 & 66.3 & 1.65 & $100 / 65$ & 0 & 8 & 288 & 16.1 & 143 & 3.8 & 37.8 & 34.7 \\
\hline F.W. & Normal & $\mathrm{F}$ & 25 & 62.5 & 1.73 & $125 / 85$ & 0 & 9 & 290 & 14.9 & 140 & 4.3 & 39.1 & 42.4 \\
\hline A.F. & Normal & M & 49 & 81.8 & 1.91 & $125 / 75$ & 0 & 13 & 297 & 16.5 & 146 & 4.8 & 37.7 & 38.3 \\
\hline T.M. & Normal & $\mathrm{F}$ & 49 & 70.5 & 1.70 & 13070 & 0 & 14 & 286 & 14.1 & 138 & 3.5 & 32.6 & 32.3 \\
\hline
\end{tabular}

* Pyelo. $=$ chronic pyelonephritis, bilateral. Polycyst. = polycystic kidney disease. Neph. = glomerulonephritis. 
tricle with a prolonged decholin circulation time but without peripheral edema.

Radioactive sodium $\left(\mathrm{Na}^{24}\right)^{1}$ and radioactive potassium $\left(\mathrm{K}^{42}\right)^{1}$ were given orally in tracer doses of 80 and $125 \mu \mathrm{c}$ respectively; 22 to 24 hours after the administration of the isotopes, serum and urine samples were obtained for the measurements of specific activity which were used for calculating exchangeable sodium $\left(\mathrm{Na}_{e}\right)$ and exchangeable potassium $\left(\mathrm{K}_{\mathrm{e}}\right)(10,11)$. Urine was also collected during the equilibration period for determination of sodium and potassium content and radioactivity excreted. After the first blood and urine samples were obtained, radiosulfate $\left(\mathrm{S}^{35} \mathrm{O}_{4}\right)^{2}$ in a dose of $50 \mu \mathrm{c}$ was administered intravenously with a calibrated syringe. Twenty minutes after the injection, serum and urine were obtained for the determination of radiosulfate space (12).

For $\mathrm{Na}^{24}$ and $\mathrm{K}^{42}$ determinations, 4-ml aliquots of serum and urine were prepared in duplicate in Lusteroid test tubes and assayed in well-type sodium iodide and plastic phosphor ${ }^{3}$ scintillation counters. By employing simultaneous equations the contribution of $\mathrm{Na}^{24}$ and $\mathrm{K}^{42}$ to the total activity of each sample was calculated (13). For $\mathrm{S}^{35} \mathrm{O}_{4}$ determinations, after the $\mathrm{Na}^{24}$ and $\mathrm{K}^{42}$ had decayed, serum proteins were precipitated with 10 per cent trichloroacetic acid and 1-ml aliquots of the supernatant were dried by infrared lamps in Pyrex planchets ${ }^{4}$ with wafers of lens paper to ensure even distribution. Urine samples were similarly prepared without protein precipitation. $\mathrm{S}^{35}$ radioactivity was counted with a thin window Geiger-Mueller tube. Standards for the radiosulfate counting were made with an aliquot of the patient's serum obtained before radiosulfate administration to correct for the water content of the serum samples. Correction was made for the Gibbs-Donnan effect by multiplying the serum value by 0.9 . Sodium and potassium were measured in urine and plasma with a lithium internal-standard flame photometer. Total solute concentration of the serum was determined by freezing point depression using a Fiske osmometer and sodium chloride standards of known osmolality. Results were expressed as serum osmolality without correcting for the contribution of serum proteins to the freezing point depression. Although serum water content was not directly determined, the "exchangeable" sodium and potassium values, calculated respectively from the specific activities of sodium and potassium in the serum and urine, were not significantly different.

Renal studies identical with those previously described (1) were also carried out in 5 of the patients with malignant hypertension. On the day of the test no medication was given. The subjects were studied in the morning in the postabsorptive state while lying supine. Urine was collected through an indwelling bladder

${ }^{1}$ Kindly supplied by Dr. A. K. Solomon, Dept. of Biophysics, Harvard Medical School, Boston, Mass.

2 Obtained from Oak Ridge National Laboratory, Oak Ridge, Tenn.

3 Obtained from Baird-Atomic, Cambridge, Mass.

4 Obtained from Tracerlab, Boston, Mass.

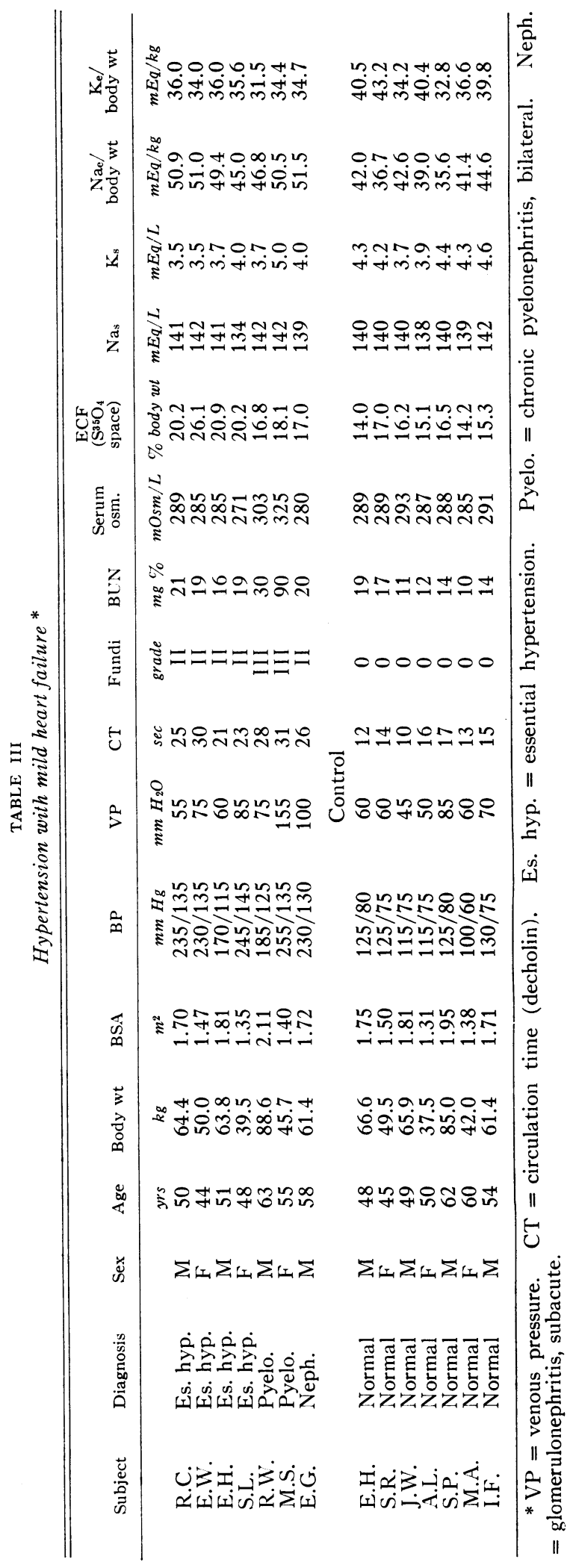


BODY FLUID AND ELECTROLYTES IN ARTERIAL HYPERTENSION

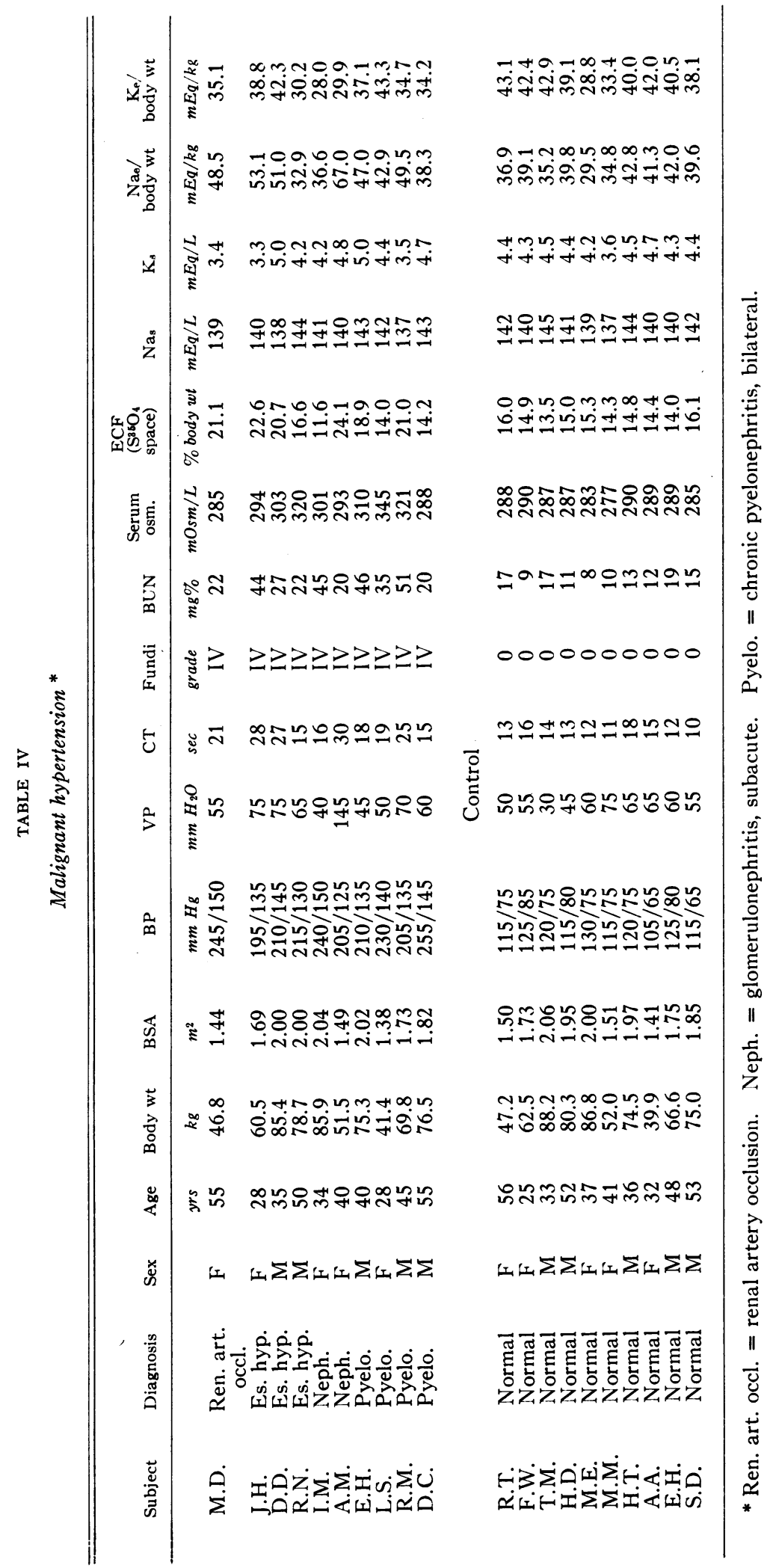


TABLE V

Sodium excrelion in malignant hypertension

\begin{tabular}{|c|c|c|c|c|c|c|}
\hline Subject & Procedure & $\mathrm{C}_{\mathrm{PAH}}$ & Cin & $\mathrm{V}$ & $\mathrm{U}_{\mathrm{NaV}}$ & $\mathrm{U}_{\mathrm{KV}}$ \\
\hline & \multicolumn{2}{|c|}{$\mathrm{ml} / \mathrm{min} / 1.73 \mathrm{~m}^{2}$} & $m l / m i n$ & \multicolumn{2}{|c|}{$\mu E q / \min$} \\
\hline M.D. & $\begin{array}{l}\text { Control } \\
5 \% \mathrm{NaCl}(300 \mathrm{ml} \text { i.v. }) \\
\text { Recovery }\end{array}$ & $\begin{array}{l}261 \\
353 \\
310\end{array}$ & $\begin{array}{r}95 \\
115 \\
101\end{array}$ & $\begin{array}{l}7.5 \\
9.9 \\
5.3\end{array}$ & $\begin{array}{l}111 \\
850 \\
855\end{array}$ & $\begin{array}{r}38 \\
107 \\
86\end{array}$ \\
\hline D.D. & $\begin{array}{l}\text { Control } \\
5 \% \mathrm{NaCl}(300 \mathrm{ml} \text { i.v.) } \\
\text { Recovery }\end{array}$ & $\begin{array}{l}225 \\
265 \\
247\end{array}$ & $\begin{array}{l}60 \\
75 \\
62\end{array}$ & $\begin{array}{r}3.8 \\
14.6 \\
7.5\end{array}$ & $\begin{array}{r}322 \\
1,581 \\
1,467\end{array}$ & $\begin{array}{r}70 \\
105 \\
74\end{array}$ \\
\hline R.N. & $\begin{array}{l}\text { Control } \\
5 \% \mathrm{NaCl}(300 \mathrm{ml} \text { i.v.) } \\
\text { Recovery }\end{array}$ & $\begin{array}{l}255 \\
290 \\
289\end{array}$ & $\begin{array}{l}71 \\
78 \\
80\end{array}$ & $\begin{array}{l}2.9 \\
8.9 \\
8.0\end{array}$ & $\begin{array}{r}235 \\
1,161 \\
1,297\end{array}$ & $\begin{array}{r}91 \\
129 \\
144\end{array}$ \\
\hline A.M. & $\begin{array}{l}\text { Control } \\
5 \% \mathrm{NaCl}(300 \mathrm{ml} \text { i.v. }) \\
\text { Recovery }\end{array}$ & $\begin{array}{l}374 \\
550 \\
522\end{array}$ & $\begin{array}{l}73 \\
83 \\
92\end{array}$ & $\begin{array}{l}2.4 \\
6.0 \\
7.5\end{array}$ & $\begin{array}{r}236 \\
746 \\
1,117\end{array}$ & $\begin{array}{r}84 \\
127 \\
128\end{array}$ \\
\hline D.C. & $\begin{array}{l}\text { Control } \\
5 \% \mathrm{NaCl}(300 \mathrm{ml} \text { i.v. }) \\
\text { Recovery }\end{array}$ & $\begin{array}{l}305 \\
333 \\
357\end{array}$ & $\begin{array}{l}81 \\
85 \\
87\end{array}$ & $\begin{array}{l}5.4 \\
5.3 \\
5.9\end{array}$ & $\begin{array}{r}301 \\
706 \\
1,131\end{array}$ & $\begin{array}{l}75 \\
68 \\
76\end{array}$ \\
\hline
\end{tabular}

catheter. Following the "control" period which consisted of 3 to 4 urine collection periods of 10 to $15 \mathrm{~min}$ utes each, $300 \mathrm{ml}$ of 5 per cent sodium chloride was administered intravenously at the rate of 10 to $12 \mathrm{ml}$ per minute. At the end of the infusion a urine collection designated as "5 per cent $\mathrm{NaCl}$ " was made. Thereafter at least 3 additional urine collections were obtained in the "recovery" period at intervals of 15 minutes. The measurements of para-aminohippuric acid and inulin clearances, and concentrations of sodium and potassium in the urine and serum were made by methods previously reported (1).

\section{RESULTS}

The measurements of body fluid and electrolytes in hypertensive and control subjects are summarized in Tables I to V. The statistical analyses of these findings are given in Table VI.

Essential hypertension. Exchangeable sodium per kilogram of weight and the radiosulfate space expressed as percentage of body weight were not significantly different in the hypertensive and control groups. Although serum sodium and blood urea nitrogen were slightly but significantly elevated in the hypertensive as compared with the control group, serum osmolality was not significantly different in the two groups. Intracellular and extracellular exchangeable sodium, as calculated from the radiosulfate spaces and serum sodium values, also did not show a significant difference in the groups $(p>0.4)$. Serum potassium and total exchangeable potassium per kilogram of weight were not significantly different in the hypertensive and control groups.

Hypertension associated with bilateral renal disease. Serum sodium, serum osmolality, radiosulfate space and exchangeable sodium in the "renal hypertensive group" were not significantly different from the values obtained in the control group. Exchangeable potassium and serum potassium were also comparable in the groups.

Hypertension complicated by mild heart failure. Exchangeable sodium and radiosulfate spaces were significantly higher in the seven hypertensive subjects who had mild heart failure without clinically detectable peripheral edema than in the control group. The increase in exchangeable sodium averaged $9 \mathrm{mEq}$ per $\mathrm{kg}$ weight or 22 per cent of the values in the control group, whereas the mean increase in the $\mathrm{S}^{35} \mathrm{O}_{4}$ space was 4.4 per cent of body weight, or 29 per cent of control values. However, serum sodium and osmolality did not differ significantly in the two groups. The mean serum potassium and exchangeable potassium were slightly reduced as compared with the control values. These differences in serum potassium were not statistically significant, but those in exchangeable potassium were significant at the 5 per cent level.

Malignant hypertension. The group with malignant hypertension as compared with the control group had significant elevations of exchangeable 


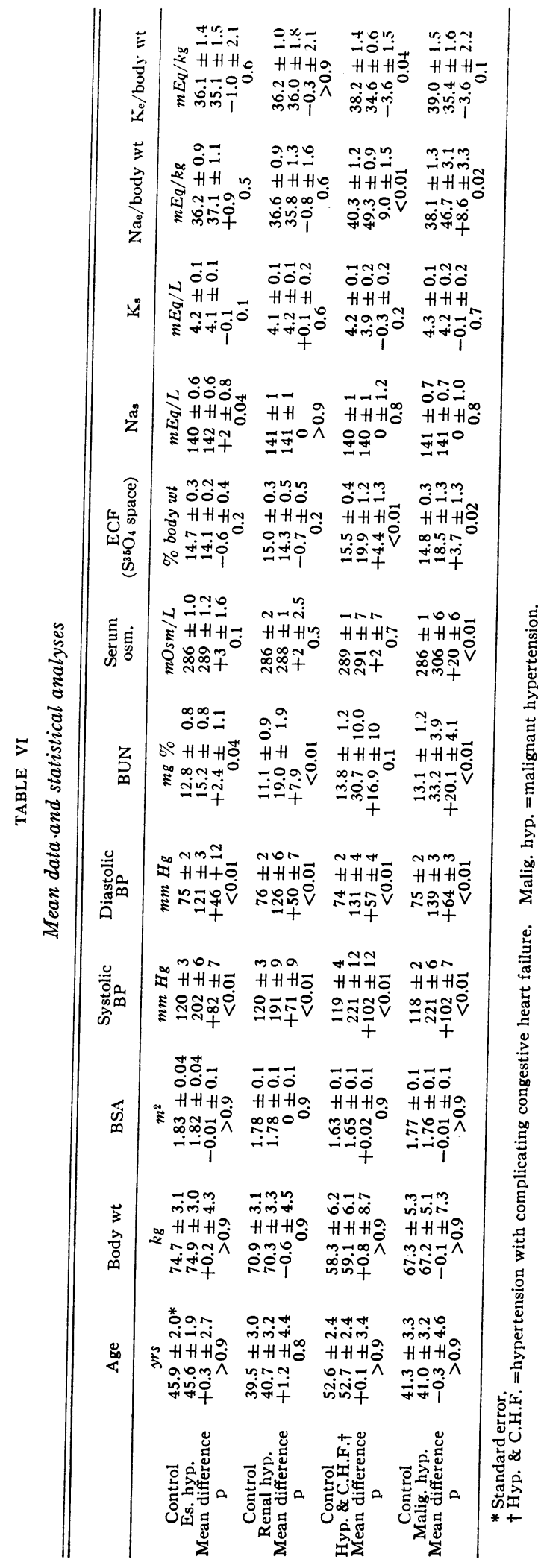

sodium per kilogram of weight and of radiosulfate space expressed as percentage of body weight. The increases in the exchangeable sodium and the radiosulfate spaces were comparable and averaged 22 and 25 per cent above control values. These changes did not occur consistently in the group but appeared to occur only when there was also a prolonged decholin circulation time. Serum sodium was comparable in the normotensive and hypertensive groups, whereas serum osmolality was significantly elevated in the hypertensive group in association with nitrogen retention. Neither serum potassium nor exchangeable potassium was significantly different in the groups, although the mean exchangeable potassium was lower in the hypertensive than in the control group by 3.6 $\mathrm{mEq}$ per $\mathrm{kg}$ of weight.

An impairment in sodium excretory capacity, as indicated by the rate of sodium excretion following a rapid infusion of $300 \mathrm{ml}$ of 5 per cent sodium chloride (Table V), was not demonstrable in five subjects with malignant hypertension, including three who had prolonged circulation times and increases in exchangeable sodium and extracellular fluid volume. The rate of sodium and potassium excretion in these five subjects was similar to that previously reported in uncomplicated hypertensive subjects and considerably higher than that found in normotensive subjects (1).

\section{DISCUSSION}

A number of conflicting reports have appeared concerning body fluid and electrolyte composition in arterial hypertension. Grollman and Shapiro have reported a slight but significant increase in the radiosulfate space in essential hypertension (14). In addition to an expanded extracellular fluid space, Ross has observed an increase in total exchangeable sodium in hypertensive subjects (15). In contrast to these observations, some other workers have found extracellular fluid volume and exchangeable sodium to be normal in arterial hypertension $(16,17)$. The current results suggest that the apparent discrepancies in these reports might be due to differences in selection and classification of the hypertensive subjects.

In the present study exchangeable sodium and extracellular fluid volume were not found to be significantly elevated in uncomplicated essential hy- 
pertension. Exchangeable potassium also was not significantly altered in this form of hypertension. The latter finding is in sharp contrast to the marked reduction in exchangable potassium found in hypertension associated with primary aldosteronism (9). Hypertension associated with renal disease also appeared to be characterized by a normal body sodium, potassium and radiosulfate space. These observations indicate that the increased capacity of hypertensive subjects to excrete sodium is not due to an expanded extracellular fluid volume nor to an increase in body sodium as was previously consiclered $(1,2)$.

In contrast to uncomplicated hypertension, hypertension complicated by congestive heart failure was accompanied by an increase in both exchangeable sodium and radiosulfate space. These changes in body sodium and fluid volume were not clinically detectable in the early stages of heart failure, since they occurred without peripheral edema or weight gain during an unrestricted dietary salt intake. An elevated radiosulfate space has likewise been observed by Walser, Duffy and Griffin in mild heart failure without peripheral edema (16). The present and previous studies indicate that these alterations in body composition may also occur without a demonstrable impairment in sodium excretory capacity (18-20). In view of these observations it is possible that the increases in body sodium and extracellular fluid volume found by Ross in a group of subjects with severe hypertension might have been due to complicating subclinical heart failure.

An increase in body sodium and extracellular fluid volume also occurred in the malignant phase of hypertension without clinically detectable edema or an impairment in sodium excretory capacity. Since this accelerated form of hypertension was frequently complicated by severe vascular disease as well as by heart failure, it is not entirely clear whether the changes in body sodium and fluid volume were related to the hypertension itself or to the complications of the disease. However, it appears that body sodium may remain normal at the onset of malignant hypertension but may increase as the hypertension becomes complicated by severe cardiovascular disease, especially congestive heart failure. Complicating heart failure, which sometimes is clinically difficult to recognize in its early stages, may also account for the marked in- crease in aldosterone activity reported in severe and malignant cases of hypertension $(5,6)$. It is unlikely, however, that an augmented aldosterone activity per se is responsible for the changes in body fluids and electrolytes in malignant hypertension and congestive heart failure, since salt and water retention is usually greater whereas potassium depletion is considerably less in these conditions than in primary aldosteronism.

\section{CONCLUSIONS}

1. In uncomplicated essential and renal hypertension, exchangeable sodium $\left(\mathrm{Na}^{24}\right.$ space), exchangeable potassium ( $\mathrm{K}^{42}$ space), extracellular fluid volume $\left(\mathrm{S}^{35} \mathrm{O}_{4}\right.$ space), and serum osmolality were not significantly different from the values obtained in control subjects.

2. In hypertension complicated by heart failure, even of a mild degree without clinically detectable peripheral edema, exchangeable sodium and radiosulfate space were significantly elevated, whereas exchangeable potassium was slightly reduced.

3. In malignant hypertension, exchangeable sodium and radiosulfate space were also significantly increased while exchangeable potassium was slightly reduced.

4. These body fluid and electrolyte patterns are significantly different from those found in the hypertension associated with primary aldosteronism.

\section{REFERENCES}

1. Hollander, W., and Judson, W. E. Electrolyte and water excretion in arterial hypertension. I. Studies in non-medically treated subjects with essential hypertension. J. clin. Invest. 1957, 36, 1460.

2. Hollander, W., and Judson, W. E. Electrolyte and water excretion in arterial hypertension. II. Studies in subjects with essential hypertension after antihypertensive drug treatment. Circulation 1958, 17, 576.

3. Birchall, R., Tuthill, S. W., Jacobs, W. S., Trautman, W. J., Jr., and Findley, T. Renal excretion of water, sodium, and chloride. Comparison of the responses of hypertensive patients with those of normal subjects, patients with specific adrenal or pituitary defects, and a normal subject primed with various hormones. Circulation 1953, 7, 258.

4. Burnett, C. H. The actions of ACTH and cortisone on renal function in man in Transactions of Second Conf. on Renal Function. New York, Josiah Macy, Jr. Foundation, 1951, p. 106.

5. Genest, J., Lemieux, G., Davignon, A., Koiw, E., Nowaczynski, W., and Steyermark, P. Human 
arterial hypertension: A state of mild chronic hyperaldosteronism. Science 1956, 123, 503.

6. Laragh, J. H., Ulick, S., Januszewicz, W., Deming, Q. B., Kelly, W. G., and Lieberman, S. Aldosterone secretion and arterial hypertension (abstract). Circulation 1959, 20, 725.

7. Garst, J. B., Shumway, N. P., Schwartz, H., and Farrell, G. L. Aldosterone excretion in hypertension. Fed. Proc. 1960, 19, 166.

8. Hollander, W., Chobanian, A. V., and Burrows, B. A. Electrolyte and water metabolism in essential, renal, and steroid-induced hypertension (abstract). Circulation 1957, 16, 893.

9. Chobanian, A. V., Burrows, B. A., and Hollander, W. Body fluid and electrolyte composition in arterial hypertension. II. Studies in mineralocorticoid hypertension. J. clin. Invest. 1961, 40, 416.

10. Burrows, B. A., and Sisson, J. H. The measurement of total body potassium by the radioisotope dilution technique (abstract). J. clin. Invest. 1950, 29, 801.

11. Hine, G. J., Jagger, P. I., and Burrows, B. A. Measurement of body radioactivity for studies of sodium metabolism. J. Lab. clin. Med. 1960, 55, 476.

12. Walser, M., Seldin, D. W., and Grollman, A. An evaluation of radiosulfate for the determination of the volume of extracellular fluid in man and dogs. J. clin. Invest. 1953, 32, 299.
13. Hine, G. J., Burrows, B. A., Apt, L., Pollycove, M., Ross, J. F., and Sarkes, L. A. Scintillation counting for multiple-tracer studies. Nucleonics 1955, 13 , no. 2, p. 23.

14. Grollman, A., and Shapiro, A. P. The volume of the extracellular fluid in experimental and human hypertension. J. clin. Invest. 1953, 32, 312.

15. Ross, E. J. Total exchangeable sodium in hypertensive patients. Clin. Sci. 1956, 15, 81.

16. Walser, M., Duffy, B. J., Jr., and Griffin, H. W. Body fluids in hypertension and mild heart failure. J. Amer. med. Ass. 1956, 160, 858.

17. DeGraeff, J. Inulin space and total exchangeable sodium in patients with essential hypertension. Acta med. scand. 1957, 156, 337.

18. Hollander, W., and Judson, W. E. The relationship of cardiovascular and renal hemodynamic function to sodium excretion in patients with severe heart disease but without edema. J. clin. Invest. 1956, 35, 970.

19. Hollander, W., and Chobanian, A. V. Further studies in electrolyte and water metabolism in cardiac patients without peripheral edema. J. clin. Invest. 1957, 36, 901.

20. Chobanian, A. V., Burrows, B. A., and Hollander, W. Electrolyte and water metabolism in cardiac patients with early congestive heart failure. Circulation 1957, 26, 866. 